\title{
Refuge
}

Canada's Journal on Refugees

revue canadienne sur les réfugiés

\section{The Coloniality of Migration and the "Refugee Crisis": On the Asylum-Migration Nexus, the Transatlantic White European Settler Colonialism-Migration and Racial Capitalism}

\section{Encarnación Gutiérrez Rodríguez}

Volume 34, numéro 1, 2018

Intersectional Feminist Interventions in the "Refugee Crisis"

URI : https://id.erudit.org/iderudit/1050851ar

DOI : https://doi.org/10.7202/1050851ar

Aller au sommaire du numéro

Éditeur(s)

Centre for Refugee Studies, York University

ISSN

0229-5113 (imprimé)

1920-7336 (numérique)

Découvrir la revue

Citer cet article

Gutiérrez Rodríguez, E. (2018). The Coloniality of Migration and the "Refugee Crisis”: On the Asylum-Migration Nexus, the Transatlantic White European Settler Colonialism-Migration and Racial Capitalism. Refuge, 34(1).

https://doi.org/10.7202/1050851ar
Résumé de l'article

Cet article se démarque de la discussion de Stephen Castles sur le lien entre l'asile et la migration en ciblant les effets politiques et culturels de l'été migratoire vécu en 2015. Il plaide pour une conceptualisation du lien entre l'asile et la migration dans le cadre de la " colonialité du pouvoir » d'Anibal Quijano, et ce en élaborant le cadre d'analyse de la " colonialité de la migration ". C'est dans ce dernier qu'il explore la connexion entre le capitalisme racial et le lien asile-migration. Pour cela, l'article cible d'abord les liens politiques et économiques entre asile et migration, et la manière dont l'un et l'autre se constituent l'un par l'autre. Sur ces bases, en établissant une nomenclature qui s'appuie sur une réminiscence fictive des pratiques orientalistes et racialisées du colonialisme et de l'impérialisme européens, il discute la manière dont les politiques d'asile et de migration produisent des catégories hiérarchiques de migrants et de réfugiés. Dans la deuxième partie, l'article cible les politiques d'asile et de migration en tant que politiques indissociables d'une logique de racialisation de la main d'œuvre. Pour cela, il explore tout d'abord le codage des données raciales des politiques d'immigration dans le contexte du colonialisme de peuplement et de la migration transatlantique des blancs d'origine européenne vers les Amériques et l'Océanie aux XIXe et XXe siècles ; il discute ensuite des politiques de migration dans l'Europe de l'Ouest de l'après-1945.
Copyright (c) Refuge: Canada's Journal on Refugees, 2018

Creative Commons Attribution NonCommercial 4.0 International License
Ce document est protégé par la loi sur le droit d'auteur. L'utilisation des services d'Érudit (y compris la reproduction) est assujettie à sa politique d'utilisation que vous pouvez consulter en ligne. 


\title{
The Coloniality of Migration and the "Refugee Crisis": On the Asylum-Migration Nexus, the Transatlantic White European Settler Colonialism-Migration and Racial Capitalism
}

\author{
ENCARNACIÓN GUTIÉRREZ RODRÍGUEZ ${ }^{1}$
}

\section{Abstract}

This article departs from the discussion by Stephen Castles on the migration-asylum nexus by focusing on the political and cultural effects of the summer of immigration in 2015. It argues for a conceptualization of the asylum-migration nexus within the framework of Anibal Quijano's "coloniality of power" by developing the analytical framework of the "coloniality of migration." Through the analytical framework of the "coloniality of migration" the connection between racial capitalism and the asylum-migration nexus is explored. It does so by first focusing on the economic and political links between asylum and migration, and how both constitute each other. On these grounds, it discusses how asylum and migration policies produce hierarchical categories of migrants and refugees, producing a nomenclature drawing on an imaginary reminiscent of the orientalist and racialized practices of European colonialism and imperialism. In a second step, it focuses on migration and asylum policies as inherent to a logic of racialization of the

(C) Encarnación Gutiérrez Rodrîguez, 2018. This open-access work is licensed under a Creative Commons Attribution-NonCommercial 4.0 International Licence, which permits use, reproduction, and distribution in any medium for non-commercial purposes, provided the original authorship is credited and the original publication in Refuge: Canada's Journal on Refugees is cited. workforce. It does so by first exploring the racial coding of immigration policies within the context of settler colonialism and transatlantic White European migration to the Américas and Oceania in the nineteenth and twentieth centuries, and second, by discussing migration policies in post-1945 Western Europe.

\section{Résumé}

Cet article se démarque de la discussion de Stephen Castles sur le lien entre lasile et la migration en ciblant les effets politiques et culturels de lété migratoire vécu en 2015. Il plaide pour une conceptualisation du lien entre lasile et la migration dans le cadre de la "colonialité du pouvoir» d'Anibal Quijano, et ce en élaborant le cadre d'analyse de la «colonialité de la migration». C'est dans ce dernier qu'il explore la connexion entre le capitalisme racial et le lien asile-migration. Pour cela, l'article cible d'abord les liens politiques et économiques entre asile et migration, et la manière dont l'un et l'autre se constituent l'un par l'autre.

Cette œuvre en libre accès fait l'objet d'une licence Creative Commons Attribution-NonCommercial 4.0 International License, laquelle autorise l'utilisation, la reproduction et la distribution de l'œuvre sur tout support à des fins non commerciales, pourvu que l'auteur ou les auteurs originaux soient mentionnés et que la publication originale dans Refuge: revue canadienne sur les réfugiés soit citée. 
Sur ces bases, en établissant une nomenclature qui s'appuie sur une réminiscence fictive des pratiques orientalistes et racialisées du colonialisme et de l'impérialisme européens, il discute la manière dont les politiques d'asile et de migration produisent des catégories hiérarchiques de migrants et de réfugiés. Dans la deuxième partie, l'article cible les politiques d'asile et de migration en tant que politiques indissociables d'une logique de racialisation de la main d'euvre. Pour cela, il explore tout d'abord le codage des données raciales des politiques d'immigration dans le contexte du colonialisme de peuplement et de la migration transatlantique des blancs d'origine européenne vers les Amériques et l'Océanie aux $\mathrm{XIX}^{\mathrm{e}}$ et $\mathrm{XX}$ e siècles; il discute ensuite des politiques de migration dans l'Europe de l'Ouest de l'après-1945.

$\mathrm{D}$ uring August and September 2015 the media constantly replayed images of refugees traversing the Balkan route to Austria, Germany, Denmark, Sweden, Finland, and Norway. This migration was initially met with hospitality through Willkommenskultur (welcome culture). However, this had changed by autumn 2015 when right-wing populists and nationalists blamed Merkel's government for allowing European societies to be "over-run" by Muslim refugees from "archaic" societies. This is exemplified in reports of New Year's Eve in Cologne 2015/16, when North African and Muslim men were accused of sexual assaults and attacks, portrayed in the media as mainly targeting white German women in the main train station. ${ }^{2}$ This reactivated the dichotomy of civilization and barbarity, constructing black and brown racialized masculinities as "premodern," lacking control over their sexuality and having a patriarchal, misogynist mindset. In political talk shows, experts reiterated that the problem was the poor adjustment of these men to the ruling "normative gender order." Their presence was interpreted by right-wing populists as a threat to Occidental civility. Politicians reacted quickly to these accusations. On July 7,2016 , the law governing sexual offences was amended to state that a sexual offence takes place when a woman's non-consent ("no means no") is not respected and when sexual attacks and harassment are committed by a group of men. This law could be understood as a slight achievement in the struggle against sexual violence. But the underlying racism, in particular anti-Muslim racism, which accelerated its passing, deserves some attention.

The New Year's Eve Event 2015/16 initiated a turning point in "the conjuncture of racism" 3 in Europe. The 2015 summer of migration transformed into a "refugee crisis." The arrival of people seeking shelter in Europe started to be publicly debated in media and politics as a "crisis," a destabilization of the social norms, and a rupture in the social order. The wealthy European countries-Sweden, Finland, Germany, and Austria-that took the biggest share of the 1.5 million people fleeing the war zones in the Middle East and Africa are not experiencing economic crisis. However, the arrival of those fleeing wars and political conflicts in the Middle East and Africa produced a "crisis" in the normative white national population. As Suvi Keskinen ${ }^{4}$ discusses, in Finland this is rather a "crisis" of "white hegemony" played out by the reshuffling of "white neonationalist femininities" and the underlying hegemonic reconstitution of their masculine counterparts. 5 Thus, the rhetoric of crisis is constructed on an ideological level.

Hall et al. ${ }^{6}$ discuss the significant role played by the media in establishing the hegemony of Thatcher's authoritarian populism in late-1970s Britain. Hall et al. identified the media construction of Black Caribbean men as "muggers" as a strategy to establish a national consensus for the Conservative government through the incessant fabrication of news on black men attacking white people on the street. This consensus was achieved by mobilizing racism. This media spectacle reiterated the British Empire's colonial vocabulary of racialization within the metropole and diverted attention from Thatcher's dismantling of the welfare state, as well as the transformation causing mass unemployment and decreasing household incomes among the working and middle classes. Instead, the media spectacle contributed to the fabrication of an outsider to the nation to whom social and economic deprivation as well as feelings of individual insecurity were attributed. Thus, the media were key actors in the formation of a hegemonic bloc supporting Thatcher's authoritarian populism. On the basis of his analysis of the political status quo, Hall ${ }^{7}$ developed his analysis of the specific conjuncture and contingency of racism. The spectacle of the black man as mugger produced an affective connection between the population and the government by creating "moral panic." At the same time, the moral panic fuelled the government responses to this "crisis" with the introduction of police "stop and search" and racial profiling. This connection between media representation, affective connections, and ideological negotiations represented a contingent moment of the specific conjuncture of racism, orchestrated by a variety of actors representing a range of convergent and divergent financial, economic, and political interests.

In the case of the production of the "refugee crisis" through media images, we have a similar convergence of media, affect, and politics. As I will develop here, the rhetoric involved in the production of the "refugee crisis" resurfaces within a specific conjuncture of racism in Europe. As I will argue, within this conjuncture colonial legacies of the construction of the racialized Other are reactivated and wrapped in a racist vocabulary, drawing on a racist imaginary combined 
with new forms of governing the racialized Other through migration control. The analysis of the media and political spectacle of the "refugee crisis" requires that we consider it as an articulation of a contingency of a specific conjuncture of racism in Europe, particularly in Germany.

I argue here that contemporary racism in Europe, particularly in Germany, is articulated by the trope of the "refugee" and the media's conjuring up of the "refugee crisis" in public and political debates. The "refugee crisis" is symptomatic of what Stephen Castles" has coined the "asylum-migration nexus" and operates within the logic of what I will call the coloniality of migration following Anibal Quijano's9 "coloniality of power." In the discussion that follows, I situate the asylum-migration nexus at the juncture of the coloniality of power and racial capitalism. ${ }^{10}$ I then extend the analytical framework of the coloniality of migration by exploring settler colonialism, transatlantic white European migration, and the racial coding of immigration policies in former colonies in the Americas and Oceania in the nineteenth and twentieth centuries, as well as migration policies in post-1945 Western Europe. The article concludes by looking at the value of the coloniality of migration as an analytical framework for the analysis of the present conjuncture of racism.

\section{Contingency: The "Refugee Crisis" and the Migration-Asylum Nexus}

By autumn 2015 there were incessant complaints about the "waves of refugees invading" Europe, and in particular Germany, in populist and social media. The "refugee crisis" was constructed as the result of lack of management by a government with no regard for the burden caused by uncontrolled migration on state welfare and social housing provision, whilst "refugees" were constructed as a threat to social cohesion. Structural inequalities were presented as resulting from the arrival of refugees and conflated with racist fantasies of Überfremdung (foreignization), a fantasy of loss of national identity and culture based on one people, race, ethnicity, religion, and language. Thus in German elections in September 2017 these sentiments resulted in an increase in votes for the right-wing populist party and the strengthening of rightwing populist positions in the conservative party, in parts of the Social Democrats and die Linke.

The right-wing populist position exposed amnesia about inter-European histories of incessant migrations and (anti-) hegemonic struggles and Europe's history of colonialism, slavery, imperialism, settler colonialism, and transatlantic migration. Within the narrative of a monocultural/ethnic/ racial/lingual nation, contemporary refugees-for example, Afghans, Somalis, Sudanese, and Syrians-seem to have no historical connection with Europe. However, these countries were colonized by European nations or have been subjected to European imperial powers. Currently, European countries take part in international negotiations on global trade and development in the countries that are home to Europe's refugees. European countries also participate in international political and military conflicts as well as in peace negotiations. However, the perception of refugees as a "crisis" in European media and political debates accentuates the refugee presence as a rupture in everyday life.

This perception is accompanied by images of refugees arriving in Europe. Hyperbolic figures became "facts" mobilized in media and political debates on the capacity of an overburdened Europe to receive refugees. This legitimized their deportation and border closures. A close look at the statistics of organizations such as the UNHCR paints a different picture of Europe being "overburdened," because the countries that receive the largest numbers of refugees are not in Europe, but in Africa and Asia. These countries are Ethiopia, Uganda, Iran, Lebanon, Pakistan, and Turkey. ${ }^{11}$ UNHCR statistics from $2016^{12}$ show that the countries receiving the largest numbers of "persons of concern"13 in Europe were Germany (1.27 million) and Sweden $(349,303) .{ }^{14}$ In relation to the total population of these countries-Germany 82.67 million and Sweden 10 million ${ }^{15}$ "refugee" numbers are a tiny percentage. These figures demonstrate that the contemporary debates on the need to control the entry and settlement of "refugees" are not substantiated by facts. Rather they are sustained by "moral panic"16 fabricated on the basis of racist fantasies about a constructed inferior, animalistic, racialized Other. As already mentioned in the introduction, Hall et al. discuss the construction of the racialized Other by analyzing the media spectacle of black bodies as routinized images in daily news and media outlets. This media representation is presented as "factual news." Yet, as Hall et al. show, the media's visual and textual vocabulary is not neutral, but is embedded in historical genealogies of representation, fuelled by political and financial interests. In late 1970s Britain, as Hall et al. demonstrate, the nation underwent a political transformation, resulting in the shrinking of the welfare state and the introduction of cuts to state ownership and public services. This period of transition from the welfare state to the liberal state is the hallmark of Margaret Thatcher's government. As Hall et al. state, as already mentioned, conservative tabloids such as the Sun or the Mirror did not draw attention to this political change which harmed the working- and middleclass population. Instead, these tabloids constructed a new fear of black Caribbean men, which they portrayed as "muggers." Hall et al's analysis shows that the media representation of "the black Caribbean man" functioned as a "floating signifier" for all kinds of racial fantasies, articulated through the sexual and existential fears and anxieties of the white population. The state's response to this spectacle of racist angst was the introduction of measures to increase social control through 
policing and racial profiling. The media representation of "mugging" contributed to the social reproduction of a matrix of racist differentiation by forging an analogy between crime and racialized black and brown masculinities. Through the racist conservative media Thatcher garnered support to popularize her law-and-order society model by channelling people's anxieties and fears towards a racist matrix of thinking the exteriority to the nation. The cooperation between politics and media resulted in the building of a hegemonic bloc that re-actualized racism in contemporary British society. In contemporary Europe, the "refugee" has become the "floating signifier."

Thus within the media rhetoric of the "refugee crisis", the signifier of the "refugee" works as a "floating signifier" representing the anxieties and fears of what the media conceived as the majority of the population, regularly imagined as white, German, abled, cis-gendered, national bodies. These anxieties and fears of the presumed population are projected onto an imagined racialized Other. Further, the link of the "refugee" with "crisis" points to the idea of rupture and singularity. As Myrto Tsilimpounidi ${ }^{17}$ notes, "crisis" can be perceived as a "perpetual frame-breaking moment that dismantles the certainties and normative narratives of nation, sovereignty, social bonds and belonging for people on the ground." "Crisis" involves financial, economic, or political life in dominant media and political discourses, but also defines a "state of being" in society that results out of a "deep political and social sense of uncertainty, precarity, and dispossession." ${ }^{18}$ Linked to refugees, the media and political rhetoric on "crisis" illustrates the continuation of the coloniality of power.

The vilification of the refugee as sexual perpetrator, potential terrorist, and destroyer of Western democratic values and beliefs signals a political shift. This shift is reflected in the vocabulary used to describe in cultural, social, legal, and political terms the living situation of people fleeing their countries due to political persecution, ${ }^{19}$ war, and other political conflicts. In the 1970s, Chileans, Argentinians, and Uruguayans were recognized as exiles in the United Kingdom, Germany, France, and Spain. ${ }^{20}$ Today, the term exile has almost disappeared from public discourse and has been replaced by asylum policies and discourses on "bogus asylum seekers." These policies and discourses are characterized by a perspective on asylum that undermines the entitlement to sanctuary for persons fleeing from violence and persecution. Further, seeking asylum is conceived as being related to unique national or regional circumstances, unrelated to an entangled history of global exploitation, imperial oppression, and capitalist expansion.

As Stephen Castles ${ }^{21}$ argues, the distinction between asylum as coercion and migration as choice disregards the fact that migratory movements are driven by global conflicts, wars, political interests, and economic dynamics. The financial crisis in 2007/8, and the wars in Afghanistan, Iraq, and Syria are forcing people to leave the destruction of their homes, neighbourhoods, villages, towns, and cities. Thus, the assumption that migration is economic, voluntary, and, as such, not the result of conditions that force people to migrate, overlooks the global entanglements in which migration occurs. When people migrate because of poverty, unemployment, and deprivation, these societal conditions are connected to political constellations, very often tied to the exercise of power by authoritarian regimes. Thus political or religious persecution might interact with economic deprivation and vice versa. The analysis by Castles of the "asylum-migration nexus" addresses the correlation between asylum and migration. This correlation has been forged further through the increasing restrictions imposed on the right to asylum since the 1990s within the EU. Asylum has become synonymous with "economic migration" because there is an assumption that asylum applications are being made by potential low-waged migrant workers looking for employment in Europe.

Since the Tampere European Council meeting in October 1999 and its confirmation through The Hague Program in 2004, the European Commission has been creating common principles and measures for migration and asylum regulations. In October 2008 the European Parliament adopted the European Immigration and Asylum Pact establish common asylum and migration policies within the EU on four levels:

1. through cooperation with the countries of origin and transit in the form of development aid;

2. a common European asylum system, in terms of the Geneva Convention and obligations of member states under international treaties;

3. integration policies; and

4. a systematic approach to the management of transnational migration movements.

These goals are achieved through a joint visa policy; cooperation and exchange of information within a common data bank; and the creation in 2005 of FRONTEX, a common European border patrol. The EU's aim is to create "common asylum procedures and a uniform status for those who are granted asylum or subsidiary protection, as well as strengthening practical cooperation between national asylum administrations and the external dimension of asylum." 22 The "external dimension of asylum" is linked to the relationship between migration policies and development aid. In "Asylum: An Integrated Approach to Protection across the EU," the EU provides financial support to "third countries," which are transit countries for refugees and migrants heading to Europe. This affects "transit countries," such as Morocco, which receives funding for the control of its borders to Europe, detention camps, and information training for immigrants. Thus "transit countries" are themselves becoming countries of immigration as the increasing 
hurdles in crossing the Eu border force people to remain in these countries. Migration has been inextricably connected to asylum through these developments and the recent approach to refugees in Europe. The link between migration and asylum has been politicized by the erosion of the humanitarian aspect of asylum; the tightening of migration restrictions; and the economic demand for labour migration. Migration is politically regulated through asylum, much as the latter is increasingly being regulated by labour migration demands. This is the asylum-migration nexus, which has been reinforced through increasing securitization since $9 / 11$.

Antonio Negri's ${ }^{23}$ analysis of war as an integrative principle in the formation of the social order (guerra ordinativa ${ }^{24}$ ) is more relevant than ever. War has become integrated into the everyday social order through the development of the rhetoric of war outside of physical war zones. ${ }^{25}$ As such, the rhetoric of war is not just "the continuation of politics by other means; it becomes the fundamental aspect of politics and legitimation." 26 The asylum-migration nexus serves this politics of legitimation in three ways. First, it manages the collateral damage and victims of global war and conflicts. Second, it secures borders when asylum seekers are increasingly treated as invaders. Third, its differentiation of causes, patterns, and trajectories of persecution and escape undermine the ethical legitimation of asylum as a humanitarian resource. Within this context, the definition of countries as "safe countries" or "countries of persecution" depends increasingly on global political conjunctures and national or European political and economic interests.

The categorization of refugees into different statuses attached to the process of application and recognition of asylum produces a hierarchical order, a nomenclature reminiscent of the orientalist and racialized practices of European colonialism and imperialism. Asylum is ruled by the governance of migration based on a range of economic interests and cultural dynamics rooted in the history of the production of the racialized Other. ${ }^{27}$ As Quijano ${ }^{28}$ asserts, European nation-states were established on the basis of a racial classification system. Since the nineteenth century, this system has been further developed through migration regulation and control. From their introduction, migration policies were coded through a racist nomenclature in former European colonies in North, Central, and South America and the Caribbean in the late nineteenth century and in Oceania and South Africa in the twentieth century. As such, migration policies as devices operating within the logic of coloniality have racializing effects.

\section{Conjuncture: Coloniality of Migration}

As W. E. B. Du Bois ${ }^{29}$ noted, modern societies are constituted through racialization. ${ }^{30}$ Racism was exported from the fifteenth and sixteenth centuries to Europe's colonized and occupied territories and developed further by European philosophical and scientific discourses in the eighteenth and nineteenth centuries ${ }^{31}$ As such, racism is the basis of the constitution of the world order and the division of the world's population. ${ }^{32}$ Within this system of racial classification that Anibal Quijano 33 defines as the "coloniality of power," social categories in ethnicity, indigeneity, race, and religion emerged, classifying the population by administrative, legal, scientific, and aesthetic categories. A system of power was developed through which relationships of governance, labour, economy, and culture were forged. This system of colonial racial differentiation set out Eurocentrism's "fundamental axes" of a modern hierarchical system through which "historical identities" were created that discerned a "new global structure of the control of labor" associated with specific "social roles" and "geohistorical places." 34 While this "racial axis has a colonial origin and character, ... it has proven to be more durable and stable than the colonialism in whose matrix it was established." 35 Relations of global trade, the organization of waged and unwaged labour, the division of work, in short, the modes of production and social reproduction of global capitalism continue to be organized by the racial matrix sustaining the coloniality of power. The coloniality of power represents the cultural predicament of racial capitalism. Further, as Maria Lugones ${ }^{36}$ asserts, the racial differentiation system intersected with a patriarchal system, which became hegemonic in early modern times (thirteenth and fourteenth centuries) in Europe ${ }^{37}$ and was exported to the colonies from the fifteenth century onwards. This constituted the "coloniality of gender." The coloniality of gender defines the universalization of a European cisgender dichotomy, which produced positions of masculine superiority and feminine inferiority. In the intersection with colonialism and racism, these categories are complicated, as when masculinity is racialized as black and brown, it is considered "animalistic" and, as such, violent and inferior. At the same time, femininity coupled with black or brown masculinity can be considered inferior and an object of sexualized exploitation and violence. Therefore, as Lugones argues, gender constitutes the matrix of the coloniality of power. ${ }^{38}$ Negotiations around femininity and masculinity, as well as normative heterosexuality configure modern societies. Gender plays a significant role in the interplay of racialization and global capitalism, fundamentally shaping the coloniality of power within asylum and migration policies.

Though not spelt out through the term coloniality, this understanding of the colonial condition and its social, political, and cultural persistence has been outlined by anticolonial thinkers such as W. E. B. du Bois, ${ }^{39}$ Eric Williams, ${ }^{40}$ C. L. R. James, ${ }^{41}$ Claudia Jones, ${ }^{42}$ and Kwame Nkrumah ${ }^{43}$ 
in their analyses of European colonialism, pointing at racisms as the shapers of modernity. As they demonstrate, the differentiation between citizen and non-citizen (alien and others) - which regulates access to the labour market, education, political participation, the health system, media, and cultural representation-was established in colony and metropole alike. Thus racism was not just exported to the colonies but existed within the fabric of European societies prior to colonization. ${ }^{44}$ Racism is not an exception to European modernity but is at its very foundation. ${ }^{45}$ For Eric Williams, the transatlantic slave trade-the Maafa-foregrounds the entanglement between European modernity and the colonial plantation economy. It is in this entanglement that migration emerges in the nineteenth century as a modern nation-state colonial tool of governing the population in racial, ethnic, national, religious, and cultural terms.

\section{Nineteenth-Century Settler Colonialism and European Transatlantic Migration}

Considering Europe's entangled global history, it is surprising that contemporary migratory movements are perceived in political and media discourses as external to Europe's history and as singular phenomena. This has not always been the case. For example, in territories marked by a history of European colonialism, settler colonialism, and transatlantic migration, such as nation-states in the Americas, Australia, ${ }^{46}$ Canada, New Zealand, and South Africa, transatlantic European migration has been foundational to the creation of these nation-states as countries of immigration. Defining themselves in the eighteenth and nineteenth centuries as "countries of settlers and immigrants," public discourses of these nation-states on national, cultural, and linguistic representation oscillated in the nineteenth century between negation or partial acknowledgement of the transcultural fabric of their societies, until today these national narratives silence the exploitation and dehumanization of the indigenous populations in these territories, ending in genocide in some cases. In Latin America the African presence 47 due to the transatlantic slave trade during the sixteenth and nineteenth centuries has also been omitted from modern nationstate building historiography. ${ }^{48}$ From the sixteenth to the nineteenth centuries approximately 13 million people from West and East Africa were enslaved and shipped to Europe and the Americas. 49

In the twenty-first century, official historiographies and governments in these countries do not acknowledge the history, governments, political struggle, intellectual and artistic presence of the people who inhabited these territories before European colonization. ${ }^{\circ}$ Nonetheless, the presence of indigenous intellectuals, artists and activists challenging the white supremacist discourse of the Eurocentric narratives of "discovery" and "country of immigration" is more publicly present than ever. ${ }^{51}$ This same narrative disclosed the continuity between European colonialism and European transatlantic migration. As Douglas Massey ${ }^{2}$ states, from 1500 to 1800 world immigration patterns were defined by European colonialism. While Europe was establishing colonial rule in Africa and Asia, approximately 48 million emigrants left Europe for the Americas, Australia, and New Zealand between 1800 and 1925.53 The settlers arriving in the Americas from Britain, Ireland, Italy, Norway, Portugal, Spain, and Sweden represented part of modern colonization. This transatlantic migration forms part of the modern European overseas colonial settlement project, coupled with ongoing settler colonialism in Oceania. Driven by the annexation of land, appropriation of raw materials, and subjugation of the indigenous population to pure exploitable labour, this project was also propelled by the economic boost produced through the transatlantic slave trade, enabling industrialization in England, other parts of Europe, and the Americas. After the official abolition of slavery in the Americas, indentured laborers were recruited from China ${ }^{54}$ and India to work in the rapidly expanding plantation industry from the late nineteenth to the early twentieth centuries, as well as impoverished, religiously and politically persecuted Europeans. 55

Though migration due to religious persecution, poverty, and epidemic menaces represents a consistent feature of European history, it was not until the late nineteenth century that migration was centre stage in the regulation and control of the nation and its others. As a biopolitical tool of governance, migration policies were engineered and implemented first in countries in transition from colonial rule to sovereign national power. The first modern migration policies were developed in the late nineteenth century in North, Central, and South America, and in parts of the Caribbean. ${ }^{56}$ Guaranteeing the political, economic, and cultural influence of former colonial powers, migration policies established a set of instruments prioritizing the recruitment of white European migrants. ${ }^{57}$ This process took place in Canada, the United States, the Spanish-speaking Caribbean, and Latin America, or in territories kept in political dependency on the English Crown until the second half of the twentieth century, such as Australia ${ }^{58}$ and New Zealand. 59

As a result of the expansion of transportation and the need for workers in rapidly expanding industries, nineteenthcentury white European transatlantic migration signalled the advent of racially structured capitalist progress, technological advancement and urbanization. The focus on racial capitalism $^{60}$ constituted the nation-states' rationale for the process of racialization in the recruitment of migrant labour and the selection of the migrant workforce via parameters of profit and efficacy in the former European colonies. The 
recruitment of white European migrants was also determined by a cultural and educational project of nation building in the former European colonies. Here, the colonial discourse of Europe as the cradle of civilization, modernity, culture and progress underpinned the nation-state project.

The newly constituted sovereign nation-states in the Americas reacted to increasing immigration by establishing policies banning certain social, national, religious, and racial groups from entry. For example, when Britain introduced its first immigration service in 1827 to promote the emigration of Irish and poor people to Canada, ${ }^{61}$ the Nova Scotia Assembly reacted by establishing a bond system for the immigrants entering the country in 1828 . The bond system set a $£ 10$ tax on the master of any migrant vessel aiming to land on Canadian shores. ${ }^{62}$ If migrants did not become a burden for the Canadian state due to sickness, old age, poverty, or immaturity, they would be refunded the bond within a year. The introduction of the bond system was preceded by discussions on race. In 1815 a group of black Bermudians entering Canada as British colonial subjects caused an uproar in the Nova Scotia Assembly, which complained to the English Crown about sending black people to Canada. The Assembly asked that they be repatriated and their further migration be prevented. ${ }^{63}$ The question of race also became prominent in the further development of the head tax system. First introduced to control migration in general in 1828 , it was also used as a tool to prevent the immigration of racialized bodies. In 1885, for example, the introduction of the Chinese head tax on Chinese immigrants deployed specific requirements in order to reduce their immigration. Chinese immigration was stopped altogether through the introduction of the Chinese Immigration Act of $1923 .{ }^{64}$ From 1908 to 1947 the Continuous Journey legislation restricted Indian immigration by foreclosing their right as British colonial subjects to migrate to Canada. This had its more tragic moment in the Komagata Maru episode of 1914. A Japanese ship Komagata Maru, carrying 376 Punjabi passengers, coming from Hong Kong was not permitted to land in Vancouver and sent to Budge Budge near Kolkata, where they were fired at, detained, and kept under surveillance for years, as they were suspected of being political dissidents. ${ }^{65}$ The Komagata Maru incident reflects the racial coding of Canada's immigration policies at this time. The "Continuous Journey" regulation was introduced in 1908, two years after immigration legislation targeting non-white people and was further elaborated in 1910 by the corresponding Immigration Acts. ${ }^{66}$ Under these acts, the list of prohibited immigrants was expanded, and the Governor-in-Council (i.e., federal Cabinet) obtained greater authority in deciding on entry, settlement, and deportation measures. Further restrictions on entry permission were defined on the basis of race. For example, Asian immigrants were required to have $\$ 200$ and Chinese immigrants $\$ 500$ in their possession before being permitted entry, while white migrants were required to have a minimum of $\$ 25$ upon their arrival. ${ }^{67}$ Thus the Continuous Passage regulation was introduced in order to hinder the entry of non-European immigrants by permitting entry only to immigrants who came "from the country of their birth, or citizenship, by a continuous journey" and using tickets "purchased before leaving the country of their birth or citizenship." In the case of the Komagata Maru, its passengers coming from India could not make a straight journey to Vancouver because they needed to stop somewhere in order to be able to do the immense crossing. This stop was China. Further, Indian nationals that succeeded in making a continuous journey needed to pay the already mentioned entry tax of $\$ 200$. The Komagata Maru event is emblematic for the racial coding of immigration laws in Canada, as it demonstrates the deeply entrenched racism shaping immigration policies at this time.

In the 1870 s the United States followed the Canadian entry tax system by passing legislation prohibiting certain groups of migrants from entering the country. In 1875, for example, Congress prohibited the entry of prostitutes, convicts, and persons with mental health issues or physical incapacities. ${ }^{68}$ In 1891 the ban was expanded to persons suffering from contagious diseases and allowed the deportation of migrants not complying with entry requirements. Some years later, such bio-political screening included the categories of race and nationality as selection criteria. Gerald L. Neuman ${ }^{69}$ asserts that the assumption that the United States of America was a country of free borders until the introduction of migration laws in 1875 is a myth. Also David Scott FitzGerald and David A. Cook-Martín ${ }^{70}$ concede that the United States had been one of the first nations to initiate racially coded naturalization and migration policies in the eighteenth and nineteenth centuries. The introduction of the Naturalization Law in 1790 reserved eligibility to naturalize to "free whites," excluding the indigenous and enslaved population from citizenship. Further, at this time the first federal migrations laws were passed. The movement between the states in this region was already regulated by the English Crown and after independence by the United States itself in the form of incipient migration regulations. These migration regulations targeted poor and sick migrants, such as laws passed in Massachusetts in 1794 penalizing "any person who knowingly brought a pauper or indigent person into any town in the Commonwealth"71 or the masters of vessels bringing "unauthorized" colonial settlers. It was not until the beginning of the nineteenth century that a difference was established between "aliens" and "colonial settlers." In 1831, laws passed in Massachusetts penalized the entry of "aliens" into us territory. Further, as 
Neuman observes, the link between slavery and racism in the regulation of the movement of black people, fleeing from slavery and seeking political asylum in states that had abolished slavery, is significant for how migration policies in the late nineteenth century would be racially coded. Already in the aftermath of the anti-colonial and anti-slavery rebellion in Saint Domingue in the early nineteenth century, black people coming to the United States were not only considered suspicious, as they were perceived as "free blacks," but their revolutionary engagement was feared because of its potential to incite revolt against racism. In 1803 the Southern States of the United States obtained an "enactment of a federal statute prohibiting the importation of foreign blacks into states whose laws forbade their entry." ${ }^{2}$ In the second half of the nineteenth century, migration regulations were explicitly guided by racial differentiation. For example, the U.S. government reacted to Chinese migration by passing the Chinese Exclusion Act in 1882.73 This Act established a system of registration whereby all Chinese workers were obliged to register or face deportation. Though in the following years this Act was challenged by lawyers, restrictions on Chinese immigration were tightened throughout the next decades. Canada also passed a Chinese Immigration Act in 1885 introducing a head tax of fifty dollars on Chinese migrants. Eleven years later, Australia passed an Immigration Restriction Bill to prevent access by Southeast Asian immigrants, followed by a "White Australian Policy" in 1904, which banned immigration from South Asia, particularly from India, as well as from Africa. ${ }^{74}$ This policy continued into the second half of the twentieth century.

Tanya Ketarí Hernández ${ }^{75}$ notes, "Debates over immigration policies in Spanish America were often couched in racial language." At the beginning of the nineteenth century the Congress of Gran Colombia (constituting what is now Colombia, Ecuador, Panama, and Venezuela) promoted settler colonialism by granting land to European migrants. Brazil and Argentina followed suit and prioritized European migration in their constitutions, arguing that this would be beneficial for technological and economic progress. Argentina actively promoted and sought European immigration after the emancipation of the enslaved population in 1853 . Between 1869 and 1895 the European population in Argentina increased from 1.8 million to 4 million, and in 1914 it was 7.9 million, 30 per cent of the population. ${ }^{76}$ This increase was not a coincidence but resulted from a concerted effort by the Argentine government to recruit European workers and gift land, as well as partially cover the cost of transportation of white European migrants in the early years. Similar developments took place in Brazil, Cuba, and Uruguay, where together with Argentina, 90 per cent of the 10-11 million European migrants who arrived between 1880 and 1930 settled. In Venezuela, after the emancipation of the enslaved population in 1854, the government's interest in white European migration was confirmed within public intellectual debates around the blanqueamiento (whitening) of the nation. 77 Through the biological metaphor of "transfusion of blood" the Venezuelan government recruited migrants from Ireland, Gran Canaria, Germany, and Italy to keep the nation white. In 1891 legislation was passed preventing nonwhite migrants from entering the country. This policy was integrated in the 1906 constitution, which explicitly prohibited any African-descendent immigration. In a similar vein, in 1890 Brazil instituted Decree No. 528, which excluded all migrants from Africa and Asia from entering the country. This decree instituted the primacy of whiteness and dispossessed the inhabitants of Abya Yala ${ }^{78}$ from their entitlement to land they had inhabited for centuries, as the migrants arriving mainly from Portugal, Italy, Spain, and Germany were thought to legally own and settle in individual allotments of this territory. Brazil states in its 1853 constitution, "The federal government shall foster European immigration, and may not restrict, limit or burden with any tax whatsoever, the entry." 79 In 1921 Brazil's Federal Law prohibited the entry of "undesirables." ${ }^{\circ 0}$ This legal regulation was factually executed, when Brazil rejected the settlement of a group of African-Americans who were planning to create a settler colony in Mato Grosso. ${ }^{81}$ Legislation preventing particularly Chinese and non-European immigration was also passed in other parts of Latin America and the Caribbean. In Haiti, legislation forbidding the entry of Syrian immigrants was introduced in $1903{ }^{82}$ Similar laws banning Armenians and Syrians were also passed in Costa Rica (1914), Panama (1909-17), and Venezuela (1919). ${ }^{83}$ Europe expanded its economic, political, legal, and cultural control over colonized territories overseas through settler colonialism-migration until the middle of the twentieth century. However, in the public discourse in Europe this white European transatlantic settler colonial-migration seems to have been forgotten. Instead, migration is considered a new issue appearing in post-1945 societies or brought by post-1970s globalization to Europe. Within this context, migration is constructed as not having any roots in Europe, and Europe itself as the epicentre of global immigration.

\section{EU Asylum-Migration Regime and Racial Differentiation}

In the late 1940s and 1950s citizens of English colonies in the Caribbean and the Indian subcontinent arrived in the United Kingdom. These British citizens were seen as exterior to the nation and constructed as immigrants. In France in the 1950 a similar situation occurred when citizens from the French North African colonies arrived in the hexagone 
(France). The presence of these (former) colonial subjects in the seat of empire challenged the public myth that European nation-states were cut off from the circuits of colonialism and imperialism. In the 1960 s and 1970 s labour migration shaped the Fordist state in Germany, France, Britain, the Netherlands, and the Benelux countries, through the recruitment of workers from the disenfranchised territories of Southern Europe, Turkey, Morocco, and (post-)colonial territories. Despite these migratory movements, Europe's memory about its own history of transatlantic settler colonialism-migration and exile was not brought to the fore. Nonetheless, the 1980 os reaffirmed that the movements of people due to political persecution, poverty, war, austerity, social constraints, cultural restrictions, lack of employment, study, leisure, or just because of their wish for change, constituted the fabric of current societies. It is within this (post-) colonial context that migration and border control measures, technologies, devices, and tropes have been engineered in the last three decades.

Migration regulation ensures that the Other of the nation/ Europe/the Occident is reconfigured in racial terms. The logic generated in this context constructs and produces objects to be governed through restrictions, management devices, and administrative categories such as "refugee," "asylum seeker," or a variety of migrant statuses. The coloniality of migration operates within this matrix of social classification on the basis of colonial racial hierarchies. Colonial difference departs from the idea that the colonized population is fundamentally different and inherently inferior to the colonizer. ${ }^{84}$ It conceives the Other as radically inassimilable, oscillating between the positions of strangeness and similarity. ${ }^{85}$ Migration policies reiterate such racialized objectification reminiscent of colonial times.

While current EU migration and asylum policies do not operate explicitly within a framework of racial or ethnic difference, by coupling nationality and the right to asylum, they construct hierarchies in the recognition or rejection of asylum in terms of nationalities. This places people in zones of recognition or rejection of the human right to liveability. ${ }^{86}$ This coupling follows from the foundation of racialized notions of the Other. While the entry of Syrian refugees to Germany was being accepted in the autumn of 2015, for instance, people from Kosovo, Albania, and Montenegro were being deported. On October 24, 2015, these latter countries were declared "safe countries of origin." However, those affected by these deportations were primarily Roma families who had fled from racist violence in their countries of origin. The perception and categorization of this group was determined in Germany not only by their national origin. As the result of Western European racism against Roma and Sinti, deeply rooted since the Middle Ages and articulated anew, they have become the objects of securitization measures. ${ }^{87}$

Further, as previously argued, the discourses on the "refugee crisis" operate within the duality of self and Other. The debate on the "refugee crisis" is determined either by the humanitarian perspective or by a regulatory approach. The humanitarian perspective emphasizes the need for wealthy nations to provide support for people fleeing from wars and conflict zones. It appeals to Christian and humanitarian traditions of charity and empathy. Instead, the regulatory approach argues for the prioritization of securing the wealth of the local population. This debate is taking place across all political party ideologies in countries with a strong welfare regime, such as in Western Europe, the Scandinavian countries, the Netherlands, France, and Germany. If we take Germany, for example, we see how the argument about the limits of the welfare state in providing support for refugees is debated by very different political actors. While there are, of course, ideological and policy-related differences between the political camps, it is surprising to see how they converge in the use of the figure of the refugee as the Other of the nation, or Europe's "exteriority" 88 However, the migrationasylum nexus does not only follow the logic of the production of a racialized exteriority to the nationally imagined and proclaimed norm of European whiteness. This nexus also operates within the dynamics of exploitation that have functioned for the last five centuries within the colonial-modern world system, and particularly within the context of nationstate migration policies since the nineteenth century.

\section{Conclusion: Racial Capitalism}

After the summer of migration in 2015, Europe turned to an autumn of racism. Events like the 2015 New Year's Eve media controversy about claims that North African men had "raped" women at the train station in Cologne, as I have already mentioned, represented this turning point. After being disciplined by Media Watch in the last decade, the German media felt it could openly voice its racism, reporting in racist terms on "North African men," mobilizing the stereotype of the black/brown man as rapist and the white national woman as victim. Supposedly in fear of the racist white supremacist mob taking over, politicians quickly instituted new deportation laws and migration restrictions for citizens with Moroccan, Tunisian, or Algerian passports. The public outcry combined with other racist articulations and attacks against refugees in Germany, Hungary, Poland, and Sweden and the Eu refusal to offer asylum drove politicians in Germany to pass a second asylum law packet, restricting family reunification for two years for subsidiary refugees. On the eve of discussions regarding the building of 
a coalition government in Germany in the winter of 2017/18, the restriction of family reunification for refugees and the deportation of Afghan refugees was again tabled.

The "refugee crisis" reveals the paradoxes in which migration evolves. Migration within the emergence of the modern nation-state in the nineteenth century in former European colonies illustrates the divide created between the insider and outsider of the nation. This divide evokes the logic of coloniality, as it creates a racial difference between the insiders, considered members of the nation, and the outsiders, considered "migrants." Thus the dichotomy between citizens and migrants is embedded in a racializing logic produced within social relations shaped by the enduring effects of colonial epistemic power. It is in this regard that I have proposed the framework of the coloniality of migration in order to analyze migration policies.

As we have seen here, the coupling of productivity, migration, and racism marked the rise of migration policies in the Americas and Oceania. The recruitment of migrant workers took place within European racial notions of sameness and strangeness. Up until the mid-twentieth century, countries like the United States, Argentina, Brazil, Australia, New Zealand, and Canada explicitly recruited white Europeans. These policies represented a continuation of settler colonialism through the implementation of European immigration policies. These immigration policies were coupled to the project of nation-state building with migrants thought and imagined as white Europeans. As such, countries such as Canada, the United States, Argentina, Australia, Brazil, Chile, and New Zealand, to name a few, were attempting to create extensions of a white Christian Europe. For example, in Argentina and Brazil the recruitment of white European migrants was officially legitimized as a means for national industrial achievement, technical progress and urban industrialisation. ${ }^{89}$ Yet, despite the restrictions applied to migration movements from non-European territories, people from the Middle East, North Africa, China, and the Caribbean still immigrated to these areas, although attempts were regularly undertaken to stop them..$^{\circ}$

As I have argued here, the link between racial capitalism and coloniality is significant for migration policies in Western Europe. Though Europe imagines itself as "raceless," it is the cradle of the invention of racial capitalism. Migration policies operate within this racializing logic, not only on the level of the organization of labour recruitment, but also through border and migration control technologies. ${ }^{91}$ For example, migration policies in the United Kingdom for Commonwealth citizens have operated within a range of restrictions, limiting or preventing the entry of these citizens to Britain by treating former colonial subjects of the British Empire as exterior to the British nation. ${ }^{92}$ Here coloniality is played out by racializing this population and creating individuals with partial rights to no rights to entry and settlement in the United Kingdom. Also the "guest-worker" programs in Germany in the 1950 s and 1960s, intended to temporarily recruit workers from Southern Europe, Turkey, Tunisia, and Morocco, converted people to interchangeable items within labour market demands.

In the current asylum-migration nexus, the "refugee" has been reduced to a potential worker. Asylum policies seem to be turning into a new way of regulating and controlling racialized labour migration. One of the measures that were agreed in the German parliament across all party lines was the introduction of "1-euro jobs for refugees" in June 2016.93 This measure was intended to initially create jobs for the 100,000 people who had arrived in Germany as refugees. The German newspaper Süddeutsche Zeitung reported that these people received only eighty cents per hour, because the costs for travel and work clothes were deducted. Here, too, recommendations from the International Labour Organisation for working standards were ignored for those given asylum. These forms of utilization recall Enrique Dussel's 94 "objectification" of the indigenous and Afro-descendent populations during the Portuguese and Spanish colonization of the Americas. Dussel describes this process as a form of "thing-ification" of the labour force. Migration policies tend to neglect the fact that "Es wurden Arbeiter gerufen und es kamen Menschen an" (They called for workers, but human beings came), as the Turkish singer Cem Karaca ${ }^{95}$ sang in the 198 os. The coloniality of migration draws attention to this fact by addressing the links between labour, capitalism, and racism. Thus, the asylum-migration nexus needs to be interrogated as an object of governance through racial/ethnic and gender differentiation, as a cultural script for understanding society and as another grammar of thinking through capital.

\section{Notes}

1 I would like to thank the guest editors, editors, and anonymous reviewers for their comments and suggestions. A very special thanks goes also to Shirley Anne Tate.

2 No evidence has been given on what happened on that night. The media spectacle produced its own figures and facts, circulating them widely in social media. For further discussion, see Beverly Weber, "We must talk about Cologne': Race, Gender, and Reconfigurations of 'Europe,"' German Politics and Society 34, no. 4 (Winter 2016): 68-86; and Zuher Jazmati and Nina Studer, "Racializing 'Oriental' Manliness: From Colonial Contexts to Cologne," Islamophobia Studies Journal 4, no. 1 (Fall 2017): 87-100.

3 Stuart Hall introduces the analysis of the "conjuncture of racism" in his discussion of Antonio Gramsci in his article "Gramsci's Relevance for the Study of Race and Ethnicity," Journal of Communication Inquiry 10, no. 5 (1986): 5-27. 
4 See Suivi Keskinen, “The 'Crisis' of White Hegemony, Neonationalist Femininities and Antiractist Feminism," Women's Studies International Forum (2018), https://www.sciencedirect.com/science/article/abs/pii/ So277539517301784.

5 For further discussion on the "crisis of white hegemony," see "Feminisms in Times of Anti-Genderism, Racism and Austerity," ed. Encarnación Gutiérrez Rodríguez, Pinar Tuzcu, and Heidemarie Winkel, special issue, Women's Studies International Forum (2018).

6 Stuart Hall, Chas Critcher, Tony Jefferson, John Clarke, and Brian Roberts introduce this term in their analysis of the rhetoric of crisis at the early stages of Thatcherism; see Policing the Crisis (London: MacMillan, 1978).

7 See Hall, "Gramsci's Relevance."

8 Stephen Castles discusses the "asylum-migration nexus" in his "Global Perspectives on Forced Migration," Asian and Pacific Migration Journal 15 (2006): 17-28.

9 See Anibal Quijano’s discussion in “Colonialidad del Poder, Eurocentrismo y América Latina," International Sociology 15, no. 2 (2000): 201-46; and Quijano, "Coloniality of Power, Eurocentrism, and Social Classification," Coloniality at Large: Latin America and the Postcolonial Debate, ed. M. Moraña, E. D. Dussel, and C. A. Jáuregui, 181-224 (Durham, nC: Duke University Press, 2008).

10 This term has been introduced by Cedric Robinson in Black Marxism: The Making of the Black Radical Tradition (1983), I referred with this term also to W. E .B. Du Bois's, Claudia Jones, Angela Davis, Enrique Dussel, and Anibal Quijano's analysis of the relationship between capitalism and racism.

11 See "Statistiken," UNHCR Deutschland, http://www.unhcr .org/dach/de/services/statistiken.

12 The UNHCR statistics on persons of concern, which includes refugees, asylum seekers, internally displaced people, and others, shows a figure of 1.27 million persons of concern in Germany by the end of 2016. This figure is composed of 669,482 people registered as refugees, 587,346 registered as asylum seekers, and 12,017 registered as stateless persons. See http://popstats.unhcr.org/ en/overview\#_ga=2.160857659.727621022.1514460020952709227.1514460020 .

13 This is a category introduced by UNHCR including refugees, asylum seekers, and internally displaced people.

14 See http://popstats.unhcr.org/en/overview\#_ga= 2.160857659.727621022.1514460020-952709227.1514460020.

15 See "UNHCR Statistics," http://popstats.unhcr.org/en/ overview\#_ga=2.160857659.727621022.1514460020952709227.1514460020, accessed December 12, 2017.

16 Hall et al. introduce this term in their analysis of the rhetoric of crisis at the early stages of Thatcherism; see Policing the Crisis.

17 See Myrto Tsilimpounidi, Sociology of Crisis: Visualising Urban Austerity (London: Routledge, 2017), 11.

18 Tsilimpounidi, Sociology of Crisis, 12.
19 "Political persecution" refers to persecutions related to sexualized, religious, and other forms of violence that threatens and damages the integrity of a person's life.

20 I discuss this aspect in Migration, Domestic Work and Affect (New York: Routledge, 2010).

21 See Castles, "Global Perspectives."

22 See "Comunicación de la Comisión al Parlamento Europeo, al Consejo, al Comité Económico y Social Europeo y al Comité de las Regiones," EuR-Lex, http://eur-lex.europa $\mathrm{eu} /$ legal-content/Es/TXT/?uri=celex:52008DC0360.

23 See Antonio Negri, Cinque lezioni di metodo su Multitudine e Impero (Soveria Mannelli: Rubbettino Editore, 2003).

24 This principle, rhetorically connecting to the idea of "bellum iustum [the 'just war'], combines two elements: the legitimacy of the military apparatus as ethically groundedthink of the human rights discourse against rogue statesand the legitimacy (qua its effectiveness) of the military action to establish the desired Other and the so-called peace" (Negri, Cinque lezioni, 25).

25 For further discussion, see Negri, Cinque lezioni.

26 Thomas Atzert and Jost Müller, eds., Antonio Negri: Kritik der Weltordnung: Globalisierung, Imperialismus, Empire (Berlin: ID Verlag, 2003), 136.

27 I develop this discussion in Migration, Domestic Work and Affect.

28 See Anibal Quijano and Michael Ennis, "Coloniality of Power, Eurocentrism, and Latin America," Nepantla: Views from South 1, no. 3 (2000): 570.

29 See here W. E. B. Du Bois, Black Reconstruction in America (1935; repr., New York: Oxford University Press, 2007).

$30 \mathrm{Du}$ Bois's analysis relates to industrial societies, but processes of racialization already took place before and during colonialization, such as the introduction of laws for the persecution of Roma, Jewish, and Muslim populations in the Spanish kingdom in the fourteenth and fifteenth century.

31 For further discussion, see Robert Bernasconi and Syboll Coole, eds., Race and Racism in Continental Philosophy (Bloomington: Indiana University Press, 2003).

32 For further discussion, see Francisco Bethencourt, Racism: From the Crusades to the Twentieth Century (Princeton: Princeton University Press, 2014).

33 See Quijano, "Coloniality of Power."

34 See Quijano, “Colonialidad del Poder," 533-6.

35 See Quijano, "Colonialidad del Poder," 534.

36 See María Lugones, “The Coloniality of Gender," Worlds \& Knowledges Otherwise 2 (Spring 2008): 1-17.

37 For further discussion on the establishment of a capitalist system operating on the divide between production and reproduction organized through a patriarchal system, see Silvia Federici, Caliban and the Witch: Women, the Body and Primitive Accumulation (San Francisco: Autonomedia, 2004).

38 For further critical discussion on the coloniality of gender, see, for example, If Amadiume, Male Daughters, Female 
Husbands: Gender and Sex in a African Society (1987; Chicago: Chicago University Press, 2015); and Yuderkys Espinosa Muñoz, "Hacia la construcción de la historia de un (des)encuentro: La razón feminista y la agencia y la agencia antirracista y decolonial en Abya Yala," Praxis: Revista de Filosofía 76 (2017): 25-39.

39 See Du Bois, Black Reconstruction.

40 See Eric Eustace Williams, Capitalism and Slavery (Chapel Hill: University of North Carolina Press, 1994).

41 See C. L. R James, The Black Jacobins: Toussaint Louverture and the San Domingo Revolution (New York: Vintage Books, 1989).

42 See the wonderful recollection of Claudia Jones's work edited by Carole Boyce Davies, Claudia Jones: Beyond Cotainment (Oxfordshire: Ayebia Clarke Publishing, 2011).

43 See Kwame Nkrumah, Class Struggle in Africa (New York: International Publishers, 2006).

44 For futher discussion, see Miriam Eliav-Felden, Benjamin Isaac, and Joseph Ziegler, eds., The Origins of Racism in the West (Cambridge: Cambridge University Press, 2009).

45 These authors deployed here develop a similar argument to Max Horkheimer and Theodor W. Adorno in regard to the analysis of anti-Semitism. As they argue, anti-Semitism represents the underside of modern Enlightenment.

46 See discussion in James Jupp, From White Australia to Woomera: The Story of Australian Immigration (Cambridge: Cambridge University Press, 2002).

47 Stuart Hall discusses the presence Africaine in "Creolité and the Process of Creolization," in Creolizing Europe: Legacies and Transformations, ed. Encarnación Gutiérrez Rodríguez and Shirley Tate, 12-25 (2003; Liverpoool: University of Liverpool Press, 2015).

48 For further discussion, see Goerge Reid Andrews, AfroLatin America, 1800-2000 (Oxford: Oxford University Press, 2004).

49 For further discussion, see David Eltis and David Richardson, eds., Extending the Frontiers: Essays on the New Transatlantic Slave Trade Database (New Haven, ст: Yale University Press, 2008)

50 For further discussion, see Glen Sean Coulthard, Red Skin, White Masks: Rejecting the Colonial Politics of Recognition (Minneapolis: University of Minnesota Press, 2014); and Audra Simpson, Mohawk Interruptus: Political Life across the Border of Settler States (Durham, NC: Duke University Press, 2014).

51 See, for example, critique from the political theorist Gladys Tzul Tzul, "Mujere indígenas: Historias de la reproducción de la vida en Guatemala," Bajo el Volcán 15, no. 2 (2015): 91-9; and in the Canadian context the critique by Eve Tuck and K. Wayne Young, "Decolonization Is Not a Metaphor," Decolonization: Indigeneity, Education \& Society 1, no. 1 (2012): 1-40.

52 See Douglas S. Massey, "The Social and Economic Origins of Immigration," Annals of the American Academy of Political and Social Sciences 510 (2000): 60-72.
53 See Massey, "Social and Economic Origins of Immigration," 62.

54 See discussion by Lisa Lowe, The Intimacies of Four Continents (Durham, NC: Duke University Press, 2015).

55 For example, see discussion on Caribbean racism by Shirley Anne Tate and Ian Law, Caribbean Racisms: Connections and Complexities in the Racialization of the Caribbean Region (London: Palgrave Macmillan, 2015).

56 For further discussion on Latin America, see, for example, Jeffrey Lesser, Immigration, Ethnicity, and National Identity in Brazil, 1808 to the Present (Cambridge: Cambridge University Press, 2013); and David S. FitzGerald and David A. Cook-Martín, Culling the Masses: The Democratic Origins of Racist Immigration Policies in the Americas (Cambridge, MA: Harvard University Press, 2014).

57 See discussion in Tanya Katerí Hernández, Racial Subordination in Latin America: The Role of the State, Custormary Law, and the New Civil Rights Response (Cambridge: Cambridge University Press, 2013).

58 While Australia gained independence from the British Crown in 1931, Britain's power remained, as the Queen was responsible for appointing state governors and giving assent to state bills. This changed through the introduction of the Australian Act in 1986, which stated that the British government was no longer responsible for the government of any state and that the Westminster Parliament could no longer legislate for Australia.

59 The 1852 New Zealand Constitution Act granted the colony's settlers the right to self-government. Yet New Zealand did not become a sovereign nation-state until 1919, though, like Australia, political ties to the Queen remain significant.

6o I refer here to discussions in du Bois, Black Reconstruction in America; and Cedric J. Robinson, Black Marxism: The Making of the Black Radical Tradition (Chapel Hill: University of North Carolina Press, 200o).

61 See Richard Plender, International Migration Law (Dordrecht: Martinus Nijhoff, 1988).

62 Plender, International Migration Law.

63 Plender, International Migration Law, 67.

64 See discussion in Valerie Knowles, Strangers at Our Gates: Canadian Immigration and Immigration Policy, 1540-1997 (Toronto: Dundurn, 1997).

65 For further discussion, see Anjali Gera Roy and Ajaya K. Sahoo, "The Journey of the Komagata Maru: National, Transnational, Diasporic," South Asian Diaspora 8, no. 2 (2016): 85-97.

66 See Ninette Kelley and Michael Trebilcok, The Making of the Mosaic: A History of Canadian Immigration Policy (Toronto: University of Toronto Press, 1998).

67 Knowles, Strangers at Our Gates, 86.

68 Knowles, Strangers at Our Gates.

69 See Gerald Neuman, "The Lost Century of American Immigration Law (1776-1875)," Columbia Law Review Association 93, no. 8 (1993): 1833-1901. 
70 See David S. FitzGerald and David A. Cook-Martín, Culling the Masses: The Democratic Origins of Racist Immigration Policies in the Americas (Cambridge, ma: Harvard University Press, 2014).

71 See Neuman, "Lost Century of American Immigration Law," 1849.

72 Neuman, "Lost Century of American Immigration Law," 1869.

73 Plender, International Migration Law, 69.

74 Plender, International Migration Law, 69.

75 Katerí Hernández, Racial Subordination in Latin America, 23.

76 Katerí Hernández, Racial Subordination in Latin America, 23.

77 Katerí Hernández, Racial Subordination in Latin America, 27.

78 Abya Yala is the term that the World Council of the Indigenous Nations has opted to use for this continent. Yala in the Kuna language means "land, territory," Abya means "whole of blood," "maternal maturity," "virgin maturity," and "land in its full maturity."

79 Katerí Hernández, Racial Subordination in Latin America, 24.

80 See discussion in Lesser, Negotiating National Identity.

81 See discussion in FitzGerald and Cook-Martín, Culling the Masses.

82 Plender, International Migration Law, 69.

83 Plender, International Migration Law, 70.

84 See discussion in Partha Chatterjee, The Nation and Its Fragments (Princeton: Princeton University Press, 1993); and George Steinmetz, “The Devil's Handwriting': Precolonial Discourse, Ethnographic Acuity, and Cross-Identification in German Colonialism," Comparative Studies in Society and History 45, no. 1 (2003): 41-95.

85 Stuart Hall analyzes this dynamic in Representation: Cultural Representation and Signifying Practices, edited by Stuart Hall, Jessica Evans and Sean Nixon (London: Sage, 1997).

86 See discussion in Lorraine Pannett, Making a Livable Life in Manchester: Doing Justice to People Seeking Asylum (Manchester: Manchester University Press, 2011).

87 For further discussion, see Ana Nichita Ivasiuc, Provincializing Citizenship: Critical Anthropological Notes on the Uses and Usefullness of "Citizenship" in the Context of the Roma Political Subject. https://www.academia.edu/11754903/ Provincialising_Citizenship._Critical_anthropological_ notes_on_the_uses_and_usefulness_of_citizenship_in_ the_context_of_the_Roma_political_subject.

88 I draw here on Enrique Dussel, The Invention of the Americas: Eclipse of the Other and the Myth of Modernity (New York: Continuum, 1995).

89 I share this observation with Lourdes Martinez-Echazabal in "Discourse of National/Cultural Identity in Latin America, 1845-1959," Latin American Perspectives 25, no. 3 (1998): $21-42$.

90 This aspect is further discussed in Elena Fiddian-Qasmiyeh, "Embracing Transculturalism and Footnoting Islam in Accounts of Arab Migration to Cuba," Interventions: International Journal of Postcolonial Studies 18, no. 1 (2016): 19-42.

91 For further discussion, see Amade, M'charek, Katharina Schramm, and David Skinner, “Topologies of Race: Doing Territory, Population and Identity in Europe," Science, Technology \& Human Values 39, no. 4 (2014): 468-87.

92 In this regard, see discussion in John Solomos, Race and Racism in Britain (Basingstoke: Palgrave, 2003).

93 See Thomas Öchsner, "Ein-Euro-Jobs für Flüchtlinge sind nur 8o-Cents-Jobs," Süddeutsche Zeitung 10, no. 6 (2016), http://www.sueddeutsche.de/wirtschaft/fluechtlingeein-euro-jobs-fuer-fluechtlinge-sind-nur-cent-jobs-1 .3027433 .

94 See Enrique Dussel, The Invention of the Americas: Eclipse of the Other and the Myth of Modernity (New York: Continuum, 1995).

95 See Cem Karaca, "Es kamen Menschen an" [Human beings arrived] in "Songs of Gastarbeiter," vol. 1, Imran Ayata and Bülent Kullukca, 2013, https://trikont.de/ shop/themen/turkische-musik-turkish-sounds/songs-ofgastarbeiter-vol-1/.

Encarnación Gutiérrez Rodríguez is professor in sociology at the Justust-Liebig-University, Giessen. She may be reached at E.Gutierrez-Rodriguez@sowi.uni-giessen.de. 